\title{
STANJE ZDRAVLJA STARIJIH OSOBA SMJEŠTENIH U SOCIJALNIM USTANOVAMA NA PODRUČJU FEDERACIJE BOSNE I HERCEGOVINE
}

\author{
Ivan Vasilj \\ Fakultet zdravstvenih studija, Sveučilište u Mostaru \\ Autor za korespondenciju: \\ Ivan Vasilj \\ ivan.vasilj@fzs.sum.ba
}

primljen: 2019, prihvaćen: 2020, objavljen: 2020.

\section{Apstrakt}

Uvod: Domovi za starije i nemoćne osobe pružaju skrb starijim i nemoćnim osobama izvan vlastite obitelji, a u sklopu stalnog smještaja osiguravaju cjelovitu skrb. Tjelesna aktivnost ima zadatak održati ili poboljšati funkcijske sposobnosti do kojih neminovno dolazi starenjem i učestalijom pojavom bolesti, također prevenira, liječi i rehabilitira određene akutne i kronične bolesti. Materijali i metode: Cilj rada bio je prikazati stanje zdravlja starijih osoba s obzirom na osnovne varijable poput dobi, spola, rizičnog ponašanja, vrste oboljenja, s posebnim osvrtom na tjelesnu aktivnost. Istraživanje je provedeno u ustanovama domova za starije i nemoćne na području Federacije Bosne i Hercegovine na području Srednjobosanske, Sarajevske, Hercegovačko-neretvanske i Zapadnohercegovačke županije. Rezultati: Istraživanjem je utvrđeno kako je veći broj osoba ženskoga spola (60\%) smješten u domovima za starije i nemoćne uz najčešću životnu dob od 75 do 79 godina života (21\%). Najčešće kronične bolesti koje su zastupljene kod ovih osoba su hipertenzija (22\%), dijabetes (21\%) i osteoporoza (4\%). Neznatno je veći udio ispitanika koji se bave tjelesnim vježbanjem (51\%), a najveći broj ispitanika ne zna koje su prednosti bavljenja tjelesnim aktivnostima (55\%). Zaključak: Možemo zaključiti kako svaka aktivnost, prilagođena pojedinom štićeniku, može osobu učiniti pokretljivijom i u konačnici zdravijom i manje ovisnom o pomoći drugih.

Ključne riječi: starije osobe, dom za starije i nemoćne, fizička aktivnost.

Mjesto istraživanja: Domovi za starije i nemoćne na području Federacije BiH 


\section{Uvod}

Pojačano starenje ukupnog stanovništva, starenje pojedinih funkcionalnih dobnih kontingenata, feminizacija "starosti", starenje radne snage, "starenje" znanja karakteriziraju stanovništvo BiH. Prema podacima Federalnog zavoda za statistiku, na osnovu popisa stanovništva, na teritoriji Federacije $\mathrm{BiH}$ u 2017. godini je prisutan manji broj stanovnika nego ranijih godina (2.201.193), a starijih od 65 godina je bilo 14,6\%. Nastavljen je negativan demografski trend karakteriziran kontinuiranim smanjenjem stope nataliteta $i$ rastom stope općeg mortaliteta, što je uvjetovalo negativan prirodni priraštaj $(-0,9 \%)$.

Razlozi za nebavljenje fizičkom aktivnosti, pored postojanja visokog stupnja svijesti odraslih o značaju fizičke aktivnosti za zdravlje, mogu biti mnogobrojni. Jedan od najčešće navođenih je nedostatak povoljne i pristupačne infrastrukture za bavljenje fizičkom aktivnosti. S aspekta javnozdravstvenog pristupa, intersektorsko djelovanje s ciljem unapređenja infrastrukture za bavljenje fizičkom aktivnosti pokazuje se prioritetnim (1). Prevencija zdravstvenih problema povezanih sa starosti povezana je sa stalnom tjelesnom aktivnosti od mladosti do duboke starosti.

Porastom životne dobi događaju se razne promjene u organizmu, promjene organa i organskih sustava, a rezultat toga su funkcijske promjene i starenje organizma. Tjelesna masa se najčešće povećava, dok se u veoma visokoj dobi smanjuje. Povećava se količina masnog tkiva kao rezultat smanjene tjelesne aktivnosti, dok unos kalorija ostaje isti kao i prije (2). Srčane bolesti su glavni uzrok smrti osoba od 60. godine. Jedna od dvije osobe od 60 godina pokazuje određenu vrstu suženja koronarnih arterija, ali oko $50 \%$ njih pokazat će kliničke znakove disfunkcije koronarnih arterija (3).

Domovi za starije i nemoćne osobe pružaju skrb starijim i nemoćnim osobama izvan vlastite obitelji, a u sklopu stalnog smještaja osiguravaju cjelovitu skrb, koja obuhvaća stanovanje, prehranu, održavanje osobne higijene, brigu o zdravlju, njegu, radne aktivnosti i korištenje slobodnog vremena (4). Tjelesna aktivnost ima zadatak održati ili poboljšati funkcijske sposobnosti do kojih neminovno dolazi starenjem i učestalijom pojavom bolesti, također prevenira, liječi i rehabilitira određene akutne i kronične bolesti $(5,6)$.

Starost, a i sama neaktivnost uzrokuju promjene koje se u pravilu mogu smanjiti i držati pod kontrolom redovitom tjelesnom aktivnošću. Fizička aktivnost može imati pozitivne učinke na smanjenje anksioznosti, stresa i depresije, održavanje mentalnog zdravlja i osiguravanje psihološke vitalnosti (6). 
Nekoliko je vrsta aktivnosti koje se uobičajeno savjetuju starijim i nemoćnim osobama, poput hodanja, plesa ili onih sadržaja koji stimuliraju funkcionalno poboljšanje rada srca, krvotoka i disanja, a koje je moguće uklopiti u svakodnevne aktivnosti (npr. igra s djecom, vrtlarenje) (7).

Cilj ovoga rada bio je utvrditi pozitivan učinak tjelesne aktivnosti na kvalitetu života kod osoba starije životne dobi, njihovo znanje o utjecaju tjelesne aktivnosti na zdravlje te bavljenje tjelesnim aktivnostima osoba starije životne dobi u domovima za starije i nemoćne na području Federacije Bosne i Hercegovine.

\section{Materijali i metode}

U svrhu razjašnjavanja pozitivnog učinka tjelesne aktivnosti na kvalitetu života kod osoba starije životne dobi te razjašnjavanja njihovoga znanja o utjecaju tjelesne aktivnosti na zdravlje i koliko se bave tjelesnim aktivnostima, urađeno je presječno istraživanje u ustanovama domova za starije i nemoćne osobe na području Federacije Bosne i Hercegovine. Postavljene hipoteze glase: Tjelesna aktivnost pomaže u poboljšanju kvalitete života kod osoba starije životne dobi te Osobe starije životne dobi smještene u domovima za starije i nemoćne nisu dovoljno informirane o utjecaju tjelesne aktivnosti na zdravlje.

Istraživanje se provodilo u Domovima za starije i nemoćne na području Srednjobosanske, Sarajevske, Hercegovačko-neretvanske i Zapadnohercegovačke županije. Ispitanici su bile osobe koje žive u domovima za starije i nemoćne. Uzorak u ovom istraživanju je prigodni jer su ispitanici lako dostupni. Kriterij uključenja bio je: oba spola, starija životna dob (od 65 i više godina), komunikativne osobe, a faktori isključenja: životna dob manja od 65 godina, nepokretne osobe, osobe s nekom težom bolesti.

Rad je napisan na temelju anketnog upitnika. Primjeri anketnih upitnika nalaze se u prilogu rada. Prvi Anketni upitnik sastoji se od 5 dijelova. Prvi dio upitnika sadrži 6 pitanja o općim podacima ispitanika, drugi dio ima 10 pitanja vezanih uz tjelesno vježbanje, a treći dio upitnika sastoji se od 5 pitanja o tome koliko su upoznati s pozitivnim učincima tjelesnog vježbanja na zdravlje i imaju li namjeru i dalje nastaviti s vježbanjem, dok četvrti dio upitnika sadrži 16 čestica o učincima tjelesnog vježbanja, od kojih su neke preuzete iz Trkulja Petković 2000. Svih 16 čestica nalazi se na skali ocjena od 1 do 5, gdje 1 označava potpuno netočno, a ocjena 5 potpuno točno. Peti dio upitnika je njihova subjektivna procjena o učinku tjelovježbe na njihovu kvalitetu života koji mogu označiti s nimalo, blago, umjereno i značajno. Svi su podaci 
numerički uneseni u programski sustav Microsoft Office Excel i statistički analizirani. Odgovori su obrađeni metodom frekvencije po varijablama te su izračunati i postotci, a rezultati su prikazani tabelarno i putem grafova.

Svim je ispitanicima usmenim putem bilo objašnjeno da se istraživanje provodi putem anonimnog anketnog upitnika i da će se podaci koristiti samo $\mathrm{u}$ istraživačke svrhe. Od svakog je ispitanika tražen usmeni pristanak na ispunjavanje anketnog upitnika. Svatko od ispitanika mogao je odustati u bilo kojem trenutku istraživanja bez potrebe navođenja razloga odustajanja.

\section{Rezultati}

Tijekom istraživanja anketirano je ukupno 135 ispitanika u domovima za starije i nemoćne.

Tablica 1. Raspodjela ispitanika u odnosu na spol

\begin{tabular}{lcc}
\hline Spol & Broj ispitanika & Postotak \\
\hline Muškarci & 54 & $40 \%$ \\
\hline Žene & 81 & $60 \%$ \\
\hline Ukupno & 135 & $100 \%$ \\
\hline
\end{tabular}

U Tablici 1. je vidljivo da je od ukupnog broja ispitanika zastupljenost muškaraca $40 \%$ u Domu za starije i nemoćne. Provedenim hi-kvadrat testom utvrđeno je da postoji statistički značajna razlika u zastupljenosti muškaraca i žena u domu za starije i nemoćne $\left(\chi^{2}=5,4, \alpha<0,05\right)$. U prosjeku su žene zastupljenije u domu za starije i nemoćne.

Tablica 2. Raspodjela ispitanika po dobi

\begin{tabular}{lcc}
\hline Dob & Broj ispitanika & Postotak \\
\hline $65-69$ & 29 & $21 \%$ \\
\hline $70-74$ & 20 & $15 \%$ \\
\hline $75-79$ & 29 & $21 \%$ \\
\hline $80-84$ & 21 & $16 \%$ \\
\hline $85-89$ & 20 & $15 \%$ \\
\hline 90 i više & 16 & $12 \%$ \\
\hline Ukupno & 135 & $21 \%$ \\
\hline
\end{tabular}

Pri obradi rezultata ankete, dob ispitanika podijeljena je u šest kategorija: 65-69 godina života, 70-74 godine života, 75-79 godina života, 80-84 godine života, 85-89 godina života te 90 i više godina. 
Najveći broj ispitanika, njih 29 (21\%), bili su iz dvije skupne životnih dobi. Jedna skupina je od 65 do 69 godina, a druga skupina je od 75 do 79 godina. Primjenom hi-kvadrat testa utvrđeno je da postoji statistički značajna razlika u raspodjeli po dobi ispitanika $\left(\chi^{2}=6,288, \alpha<0,05\right)$

Tablica 3. Prikaz dužine boravka u domu za starije i nemoćne

\begin{tabular}{lcc}
\hline Boravak u domu & Broj ispitanika & Postotak \\
\hline $0-3$ god. & 75 & $56 \%$ \\
\hline $4-7$ god. & 40 & $30 \%$ \\
\hline $8-11$ god. & 11 & $8 \%$ \\
\hline 12 i više god. & 9 & $7 \%$ \\
\hline Ukupno & 135 & $100 \%$ \\
\hline
\end{tabular}

Iz tablice 3. je vidljivo da najveći postotak ispitanika boravi u domu 3 godine ili manje, njih $56 \%$. Na razini statističke značajnosti $p=0,05$ utvrđena je signifikantna razlika u broju ispitanika prema godinama boravka u domu $\left(\chi^{2}=85,059, \alpha<0,05\right)$

Tablica 4. Prikaz članova obitelji

\begin{tabular}{lcc}
\hline Članovi obitelji & Broj ispitanika & Postotak \\
\hline Bračni drug i/ili djeca & 78 & $58 \%$ \\
\hline Bez uže obitelji & 57 & $42 \%$ \\
\hline Ukupno & 135 & $100 \%$ \\
\hline
\end{tabular}

Iz tablice 4. vidljivo je da 58\% ispitanika od živućih članova obitelji imaju bračnog druga ili djecu, dok je bez uže obitelji njih 42\%. Primjenom hi-kvadrat testa nije utvrđena statistički značajna razlika između ove dvije skupine ispitanika $\left(\chi^{2}=3,26, \alpha<0,05\right)$.

Tablica 5. Prikaz bolovanja od nekih kroničnih bolesti

\begin{tabular}{lcc}
\hline Kronične bolesti & Broj ispitanika & Postotak \\
\hline Hipertenzija & 30 & $22 \%$ \\
\hline Dijabetes & 29 & $21 \%$ \\
\hline Osteoporoza & 5 & $4 \%$ \\
\hline Drugo & 45 & $33 \%$ \\
\hline Ne & 26 & $19 \%$ \\
\hline Ukupno & 135 & $100 \%$ \\
\hline
\end{tabular}


Iz tablice 5. vidljivo je da najveći postotak ispitanika koji su popunili anketu ima kroničnu hipertenziju (22\%). Primjenom hi-kvadrat testa utvrđena je statistički signifikantna razlika u pojavnosti kroničnih bolesti kod ispitanika u domu za starije i nemoćne $\left(\chi^{2}=30,44, \alpha<0,05\right)$.

Tablica 6. Bavljenje tjelesnom aktivnosti u domu za starije i nemoćne

\begin{tabular}{lcc}
\hline \multirow{2}{*}{ Anketno pitanje } & \multicolumn{2}{c}{ Odgovor ispitanika } \\
\cline { 2 - 3 } & $\mathrm{da}$ & ne \\
\hline Organizirana aktivnost u domu & $50(37 \%)$ & $85(63 \%)$ \\
\hline Savjet za vježbanje & $78(58 \%)$ & $57(42 \%)$ \\
\hline Bavljenje tjelesnim vježbanjem & $69(51 \%)$ & $66(49 \%)$ \\
\hline Bavljenje tjelesnim aktivnostima prije & $35(26 \%)$ & $100(74 \%)$ \\
\hline Znanje o prednostima bavljenja tjelesnim aktivnostima & $61(45 \%)$ & $74(55 \%)$ \\
\hline Sprječavanje bolesti tjelesnim aktivnostima & $69(51 \%)$ & $66(49 \%)$ \\
\hline Želja za većim znanjem o utjecaju tjelesnih aktivnosti na zdravlje & $23(51 \%)$ & $22(49 \%)$ \\
\hline
\end{tabular}

Manji postotak ispitanika bavi se organiziranom aktivnošću u domu za starije i nemoćne. Postoji statistički značajna razlika između ispitanika koji se bave nekom organiziranom aktivnošću i onih koji se ne bave organiziranim aktivnostima $\left(\chi^{2}=9,07, \alpha<0,05\right)$.

Kada je u pitanju dobivanje savjeta medicinskog osoblja za vježbanje (tablica 6.), nema statistički značajne razlike u broju ispitanika koji su dobili savjet medicinskog osoblja za vježbanje i onih koji nisu dobili takav savjet $\left(\chi^{2}=3,26, \alpha<0,05\right)$. Primjetno je da postoje razlike u dijeljenju savjeta po pojedinim domovima (tablica 7.)

Kada je riječ o bavljenju tjelesnim vježbanjem u domu za starije i nemoćne (tablica 6.), vidljivo je da je jednak broj ispitanika koji se bave tjelesnim vježbanjem (51\%) kao i onih koji se ne bave tjelesnim vježbama (49\%).

Tablica 7. Prikaz vježbanja u tjednu

\begin{tabular}{lcc}
\hline Vježbanje u tjednu & Broj ispitanika & Postotak \\
\hline $1-2 x$ & 15 & $22 \%$ \\
\hline $3 x$ & 27 & $39 \%$ \\
\hline Više od 3x & 27 & $39 \%$ \\
\hline Ukupno & 69 & $100 \%$ \\
\hline
\end{tabular}

Iz tablice 7. vidljivo je da nema statistički značajne razlike u broju tjednih treninga kod ispitanika koji redovno vježbaju $\left(\chi^{2}=4,17, \alpha<0,05\right)$ 
Tablica 8. Prikaz perioda vježbanja

\begin{tabular}{lll}
\hline Period vježbanja & Broj ispitanika & Postotak \\
\hline <od 6 mj. & 8 & $12 \%$ \\
\hline 6 mj. -1 god. & 12 & $17 \%$ \\
\hline $1-2$ god. & 17 & $25 \%$ \\
\hline $2-3$ god. & 9 & $13 \%$ \\
\hline $3-4$ god. & 6 & $9 \%$ \\
\hline $4-5$ god. & 5 & $7 \%$ \\
\hline$>$ od 5 god. & 12 & $17 \%$ \\
\hline Ukupno & 69 & \\
\hline
\end{tabular}

Iz tablice 8. je vidljivo da nema značajnije razlike između broja ispitanika u vremenskim skupinama koji se bave tjelesnim aktivnošću. Ipak, najviše ispitanika se bavi vježbanjem u periodu od 1-2 godine.

Tablica 9. Prikaz načina vježbanja

\begin{tabular}{lcc}
\hline Način vježbanja & Broj ispitanika & Postotak \\
\hline Sam/a & 41 & $42 \%$ \\
\hline U grupi & 39 & $40 \%$ \\
\hline U paru & 17 & $18 \%$ \\
\hline Ukupno & 97 & $100 \%$ \\
\hline
\end{tabular}

Kada je u pitanju način vježbanja (tablica 11.), vidljivo je da ispitanici najmanje vježbaju u paru (18\%), također je i statistički dokazano da postoji jasna razlika između ovih grupa $\left(\chi^{2}=10,96, \alpha<0,05\right)$.

Što se tiče bavljenja tjelesnom aktivnošću prije dolaska u dom (tablica 6.), postoji statistički značajna razlika između grupe ispitanika koji su se bavili tjelesnom aktivnošću prije dolaska u dom u odnosu na grupu ispitanika koji se nisu bavili nikakvom aktivnošću. $\left(\chi^{2}=31,29, \alpha<0,05\right)$.

Tablica 10. Prikaz mišljenja o bavljenju tjelesnim aktivnostima u odnosu na druge osobe iste dobi

\begin{tabular}{lll}
\hline Mišljenje o bavljenju tjelesnim aktivnostima u odnosu na druge osobe iste dobi & Broj ispitanika & Postotak \\
\hline Veća & 56 & $41 \%$ \\
\hline Mnogo veća & 10 & $7 \%$ \\
\hline Manja & 24 & $18 \%$ \\
\hline Ista & 45 & $33 \%$ \\
\hline Ukupno & 135 & $100 \%$ \\
\hline
\end{tabular}


Najveći broj ispitanika, njih 56 (41\%), izjasnio se da smatra da ima veću razinu tjelesne aktivnosti u odnosu na druge osobe. Njih 45 (33\%) smatra da ima istu razinu, a da manju razinu aktivnosti imaju smatra 24 (18\%) ispitanika. $7 \%$ ispitanika, tj. njih 10, smatra da imaju mnogo veću razinu tjelesne aktivnosti od ostalih. Primjenom hi-kvadrat testa dokazana je statistički značajna razlika između ovih grupa ispitanika $\left(\chi^{2}=37,94, \alpha<0,05\right)$.

\section{Rasprava}

Prema rezultatima dobivenim u ovom istraživanju može se zaključiti kako postoji potreba dodatne edukacije medicinskih sestara i drugog osoblja koje je ključno za proširivanje znanja o tjelesnoj aktivnosti te kako ona utječe na zdravlje. Također treba povećati motiviranost starijih osoba za tjelesnom aktivnošću. U okviru ovog istraživanja najveći broj ispitanika bio je iz skupine od 65 do 69 godina $(29$ - 21\%) te druge skupine od 75 do 79 godina (29 $21 \%$ ), što govori u prilog kako je dob ispitanika u domovima za starije i nemoćne nešto niža u odnosu na dob ispitanika u nekim drugim istraživanjima $(37,38)$. Prosječna duljina boravka u domu za starije i nemoćne je do 3 godine, i to njih $62 \%$, i slična je u usporedbi sa sličnim istraživanjima $(37,38)$.

Vidljivo je kako je broj ispitanika koji se izjasnio da zna koje su prednosti bavljenja tjelesnom aktivnosti manji (45\%) od broja ispitanika koji se izjasnio da ne zna (55\%). Iako se radi o manjem uzorku te nismo uočili statistički značajnu razliku između onih koji znaju o pozitivnim učincima i onih koji ne znaju, dobiveni nalazi u ovom istraživanju mogu se tumačiti kao detekcija nedovoljnog znanja starijih osoba o utjecaju tjelesne aktivnosti na zdravlje.

Što se tiče udjela fizički aktivnih ispitanika u odnosu na osobe koje se ne bave fizičkom aktivnošću, vidljivo je kako je jednak broj ispitanika koji se bave tjelesnim vježbanjem (51\%) kao i onih koji se ne bave tjelesnim vježbama (49\%). U usporedbi s drugim sličnim istraživanjem (38), gdje se $71 \%$ štićenika bavi vježbanjem, radi se o dosta nižem udjelu fizički aktivnih štićenika u domovima za starije i nemoćne na području Federacije Bosne i Hercegovine.

Iako nemamo dovoljno veliki uzorak ispitanika, može se sa sigurnošću reći kako je pozitivna činjenica da se prije smještaja u dom tjelesnim aktivnostima bavilo samo njih $26 \%$, dok je broj ispitanika koji su se počeli baviti fizičkom aktivnošću popeo na 51\%. Time dolazimo do zaključka da su ispitanici zainteresirani za tjelesnu aktivnost, provode je te se interes povećava dolaskom u dom. S druge strane, hipoteza o znanju ispitanika o pozitivnim 
utjecajima tjelesne aktivnosti na zdravlje se potvrđuje - ispitanici vrlo malo znaju o tome koje se bolesti mogu prevenirati redovitom tjelesnom aktivnošću, a većina njih ne zna koje su prednosti tjelesne aktivnosti.

\section{Zaključak}

U Federaciji Bosne i Hercegovine, kao i na području susjednih država, udjel stanovništva starijeg od 65 godina prema predviđanjima će sve više rasti. U skladu s navedenim, sve je veća potražnja i potreba za smještaj u domovima za starije i nemoćne. Sustavnim uvođenjem programa fizičke aktivnosti u domove za starije i nemoćne prevenirali bi se rizici za bolesti koje su vrlo često prisutne kod starije populacije. Primijećeno je kako su ispitanici jako zainteresirani za bavljenje nekom od vrsta fizičkih aktivnosti koje im savjetuju zaposlenici domova. U prilog tome stoji i činjenica kako se broj osoba koje se bave fizičkom aktivnošću udvostručio nakon dolaska u dom. Važna je uloga uprave i zaposlenika u savjetovanju i širenju znanja njihovih korisnika o važnosti tjelesne aktivnosti za njihovo zdravlje. Oni mogu organizirati i zajedničko provođenje tjelesnih aktivnosti, što često daje vrlo dobre rezultate u odnosu na fizičku aktivnost koje osobe provode same. Možemo zaključiti kako svaka aktivnost, uz mjere borbe protiv pušenja, alkoholizma i aktivnosti prema zdravijem načinu prehrane, može osobu učiniti pokretljivijom i u konačnici zdravijom te manje ovisnom o pomoći drugih.

\section{Reference}

1. Zavod za javno zdravstvo Federacije Bosne i Hercegovine. Dostupno na: http://www. zzjzfbih.ba/wp-content/uploads/2018/10/Zdravstveno-2017.pdf str. 74. (pristupljeno 23. 12. 2018). Duraković, $Z$ i sur. Medicina starije dobi. Zagreb, 1990.

3. Dahm D, Smith J. Klinika Mayo: tjelovježba za svakoga. Zagreb, 2010.

4. Šostar Z, Fortuna V. Vodič za starije građane grada Zagreba. Zagreb, 2009.

5. Galić S, Tomasović Marčela. Priručnik iz gerontologije, gerijatrije i psihologije starijih osoba - psihologije starenja. Osijek: Medicinska škola, 2013.

6. Lok, N, Lok, S, Canbaz, M. The effect of physical activity on depressive symptoms and quality of life among elderly nursing home residents: randomized controlled trial. Archives of gerontology and geriatrics. 2017;70:92-8.

7. Heimer S, Rakovac M. Tjelesno vježbanje u zaštiti i unapređenju zdravlja. Zagreb: Kineziološki fakultet Sveučilišta u Zagrebu, 2006.

8. Krtalić S, Krstičević T, Knjaz D. Starenje i tjelesna aktivnost. Hrvat. Športskomed. Vjesn. 2016;31:3-8.

9. Buneta O, Didović I. Utjecaj tjelesne aktivnosti na ravnotežu u starijoj životnoj dobi. Physiotherapia Croatica. Rijeka. 2016;14:1.

10. Edwards P, Tsouros, AD. Promicanje tjelesne aktivnosti i aktivnog života u gradskim sredinama - uloga lokalnih vlasti. Kineziološki fakultet Sveučilišta u Zagrebu, 2009. 
Posebna izdanja ANUBiH CXCIV, OMN 58, str. 29-39

11. Tuskar N. Sportska rekreacija za osobe starije životne dobi. Međimursko veleučilište u Čakovcu, Specijalistički diplomski stručni studij menadžmenta, turizma i sporta, 2017.

12. Močnik A, Neuberg M, Canjuga I. Tjelesna aktivnost starijih osoba smještenih u stacionarnim ustanovama. Technical journal. Varaždin. 2015;9(1):112-9. 


\title{
HEALTH STATE OF ELDERLY PEOPLE PLACED IN SOCIAL CARE INSTITUTIONS IN FEDERATION OF BOSNIA AND HERZEGOVINA
}

\begin{abstract}
Introduction: Homes for the elderly and infirm provide care for the elderly and infirm outside their own family environment, and as part of permanent accommodation they also provide comprehensive care. Purpose of physical activity is maintaining or improving the functional abilities that inevitably deteriorate with aging and more frequent occurrence of illnesses. It also prevents, treats and rehabilitates certain acute and chronic diseases. Materials and methods: The aim of this paper was to present the state of health of the elderly with respect to basic variables such as age, gender, risk behaviours, types of diseases - with special reference to physical activity. The research was conducted in institutions of homes for the elderly and infirm in the Federation of Bosnia and Herzegovina in the Central Bosnia Canton, Sarajevo Canton, Herzegovina-Neretva Canton and West Herzegovina Canton. Results: The research found that a larger number of females $(60 \%)$ were placed in homes for the elderly and infirm, with the most common age of wards being 75 - 79 years $(21 \%)$. The most common chronic diseases present in these individuals are hypertension $(22 \%)$, diabetes $(21 \%)$, and osteoporosis (4\%). A slight majority of respondents engage in physical exercise $(51 \%)$, and the majority of respondents do not know the benefits of engaging in physical activity $(55 \%)$. Conclusion: We can conclude that any activity, tailored to an individual ward, can make a person more mobile and ultimately healthier and less dependent on the help of others.
\end{abstract}

Keywords: elderly, home for elderly and infirm, physical activity. 